\title{
East-European Critical Thought: Myth, Religion, and Magic versus Literature, Sign and Narrative
}

\author{
Dennis Ioffe
}

check for updates

Citation: Ioffe, Dennis. 2021. East-European Critical Thought: Myth, Religion, and Magic versus Literature, Sign and Narrative. Religions 12: 717. https://doi.org/ 10.3390/rel12090717

Received: 23 August 2021

Accepted: 27 August 2021

Published: 2 September 2021

Publisher's Note: MDPI stays neutral with regard to jurisdictional claims in published maps and institutional affiliations.

Copyright: (C) 2021 by the author. Licensee MDPI, Basel, Switzerland. This article is an open access article distributed under the terms and conditions of the Creative Commons Attribution (CC BY) license (https:// creativecommons.org/licenses/by/ $4.0 /)$.
Département D'enseignement de Langues et Lettres, Faculté de Lettres, Traduction et Communication, Université Libre de Bruxelles, Campus du Solbosch, CP 175, Avenue F.D. Roosevelt, 50, 1050 Bruxelles, Belgium; Denis.Ioffe@ulb.be

\begin{abstract}
The Introductory article offers a general overview of the highly complicated topic of religious and mythological consciousness discussed in sub-species narrative critique and literary theory. It also provides a detailed context for the wide array of religious matters discussed in this special volume of Religions. Each of the nineteen papers is positioned within its own particular thematic discourse.
\end{abstract}

Keywords: Russian Paganism; mythology; theory; narrative; semiotics \& semiosis

Our special edition concentrates on Slavic religions and mythology as evidenced in theory, literature and folklore. The nineteen articles deal with various forms of preChristian religious beliefs, myths and ritual practices of the Slavs, which infiltrate into 'dual beliefs' (such as remnants of 'dvoeverie'). Also addressed are the uneasy ways in which Christian Orthodoxy has handled the various challenges posed by popular belief and mythology. Most existing studies are somewhat dated, prompting a growing need for fresh scholarly approaches and reassessments concerning both officially sanctioned and heterodox religious practices. A basic aim, therefore, is to bring together archaic forms of religious spirituality, creative literature, folklore, philosophy and theology, a synthesis which, we hope, will illumine the ways in which mythologies and religious traditions inform ideas and artistic practices, past and present.

One of the underlying and unifying elements here is myth. After all, religion begins and ends with myth, while the contemporary endurance of myth and the complex cultural theoretical suggestions associated with its cultural and literary usage remain entirely relevant and topical. In the prevailing concept of myth, one can discern a general totality of sacred truths, as it were, parallel to daily human routine. A pioneer of myth theory as applied to the social fabric, French classical scholar Vernant (1996) contrasted myth with the practical notion of logos, even though, initially, they coincided in the etymona of their

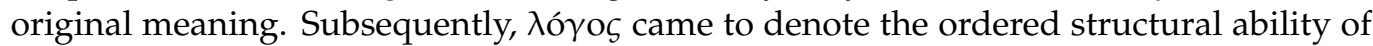
thinking, signifying — eventually — even the (Kantian) isolated mind, while myth drifted away into the Imaginarium of sacredness and narrative fiction.

Myth(ological) and 'mythogenic' modes of consciousness have driven extensive research in the humanities, generating a variety of interpretations in dictionaries, encyclopedias, reference books, scientific tracts and popular books and articles, deriving its primary school of thought from Soviet Russia ${ }^{1}$. Formulating a parallel question in their primary investigations (rather [quint]essential for Russian-language research on 'mythologism') and providing a new definition of the ambiance existing between myth and literature, prominent Soviet theorist Yuri Lotman and his colleagues and co-authors Zara Mintz and Eleazar Meletinsky discussed the gradual diffusion and submergence of 'the field of mythological and historical and everyday narrative texts' into those general literary studies researching "sacral-magical function peculiar to myth" (Lotman et al. 1987)—while, on the 
other hand, semiotically, we are treating of the practical tasks inherent in codified meanings of the secondary type.

In their provisional definitions of myth, mythological consciousness and language, various commentators have focused on the contingent semiotic signification of the codified message (Barthes 2004), ${ }^{2}$ the cultural meaning and perception of the individual and the surrounding symbiotic environment, including political conflict or propaganda (as, for example, in Eliade 2000). Others have touched on the duality of the mythic as a special kind of narrative, including its connection with ritual-which represents two important aspects (mythological and iconic) of primitive culture (see Tokarev and Meletinsky 1987; Turner 1983). When using the term 'myth', we tend to refer to extant ancient narratives about the nature of the gods, the creation of the world, and the origin/genesis of all beginnings, where cosmogonic narratives or "myths about the origin of the world, the universe, and man" (Toporov 1987), describe the space-time parameters of the multifaceted universe. Creationist myths cover the very emergence of the universe, its minor planets, all physical and material beings, images and things, as well as the primary division of the main elements: water, fire, earth and air. Vladimir Toporov distinguished inter alia two working structural stages in the mythological histories of human civilizations (2010, p. 29): the first, as a rule, deals with what was before the ultimate act of creation, while the second deals with the logical division of the world and the creation of the primary elements of the physical universe. Myth, therefore, is primarily an attempt to seek and find a satisfactory answer to questions about the origin of the nature of things in the broadest sense of these words. Indeed, one of the most crucial ideas of mythology is to bring order to disorder or transform 'unsigned chaos into semiotic cosmos' (Toporov 2010, p. 22; see also Grygar 2007; Meletinsky 2000, p. 27).

One unifying and multifaceted syncretism characteristic of mythological consciousness is, in Eliade's terms, the 'aspects' of myth and the mythical (whether ritualistic, artistic or just narrative) and the original status of 'authorship' in the mythological system of coordinates. The 'absent' author in myth is, in fact, not only 'unconscious' but in a sense even '(self)-uncreated' in the emergence of the magical myth itself. It is no coincidence that one of the authors of the literary concept, autocide (see Ioffe 2008b)_Barthes (2004) was

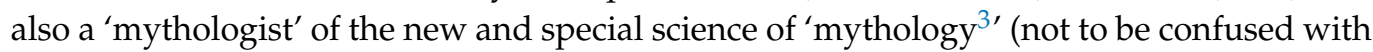
Claude Levi-Strauss' 'Mythologies'). The nameless collectivity of narrative creationism is an important hallmark of any classical mythmaking. Any descriptor or 'author of myth', whether Hesiod or (pseudo) Apollodorus, is only a retranslator of something 'alien' (in Bakhtinian terms), merely transmitting a tradition already in existence. At the same time, the main goal of myth remains unchanged, i.e., it is always the creation of a kind of ordered cosmos of naming out of the chaos of the nameless (and wordless) natural forces, although whether myth is yet another genre of literature or folklore, or whether, on the contrary, it is a special form of original philosophy or scientific ideology lies beyond the scope of this enquiry. After all, the traditional understandings of myth within the framework of the so-called 'anthropological school' (i.e., Taylor-Lang-Fraser) ${ }^{4}$ or the 'mythological school' (i.e., Muller and the Grimm brothers) are well known, so there is little sense in describing them here.

The sacral function of myth emerges parallel to the various paradigmatic aspects of magic. In fact, to perceive magic as a set of ritual-symbolic relations, rules, practices, and related representations, actions, texts and objects aimed at manipulative contact with the supernatural (sacred, or numinous, in the terminology of Rudolf Otto; see Otto 2008) is entirely feasible-yet another mode of influencing the visible world by mobilizing the forces of the invisible. Magic differs both from religion and from scientific or rational knowledge, but shares characteristics with both (see Versnel 1991; Tambiah 1990; Wax and Wax 1963; Thorndike 1958). The pragmatic purpose of ritual sacral magic is to try to alter the material ('visible') world by manipulating individual forces and energies of the spiritual ('invisible') world by applying special registers and laws, as well as ad hoc principles and rules, whereby these forces and energies must be subservient. It is the instrumental 
and manipulative "techno"-aspect of magic which differs from religious and mysticalphilosophical teachings and practices aimed at contemplative experience-a special kind of knowledge of the sacred and a unity therewith, but one devoid of utilitarian application.

The mythological essence of magic can be clarified in part by reference to the etymology of this term itself: the Greek $\mu \alpha \dot{\alpha}$ o $\zeta$ (mágos, plural magoi) meant magician or sorcerer

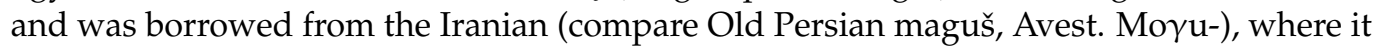
first meant a representative of one of the Median tribes and later a member of the estate or religious caste of healers and (Zoroastrian) priests (Buck 1949, pp. 1494-96; Frisk 1960, pp. 156-57). The term goes back to the root *magh-*, i.e., "to be able to articulate power". The priests, thus, were characterized as "powerful", "having (power)", and magical in their acquisition of (supernatural) power, allowing one to achieve goals, purposeful in their original, religious sense. Mágos is close to the Greek word góes- - the ancient designation of magician, as well as astrologer, and, in general, bearer of any esoteric and occult knowledge, including early alchemy. The earliest mention of the term mágos is found in fragments of the writings of Heraclitus, 6th century BC (Ioffe et al. 2017).

Mytho-magical practices have been known since ancient times. At the same time, there is no strong evidence to suggest that magic corresponds to any of the specific stages of the development of a society (no matter how we define these stages), i.e., magic might be present at a certain point, but recedes at another. Magical actions, texts and objects were part of various pagan cults, although it is virtually impossible to draw a clear line between magic and religion (especially pagan). Pagan religions create pantheons of characters, coupled with stable legends (myths) pertaining to their deeds, creating sacred precedents, and establishing codices of rituals and rules aimed at influencing these characters and interacting with them. In this context paganism intersects with magic, something which also determines the rules of this interaction and, more broadly, the ways in which it can influence the invisible world, and thereby, the visible one.

The mythogenic (myth- and narrative-generating) legacy of world literature-a basis for further neoreligious neomythologism - can be observed in the culture of European classicism: Medea and Oedipus by Corneille or Thebes, Andromache, Iphigenia in Aulis, Phaedra by Racine. In the more complex, pre-modern period of the Enlightenment, we find a quaint version of 'rational neomythology', for example, in some of Voltaire's texts such as Merope, Mahomet, Oedipus, or, conversely, in Friedrich Gottlieb Klopstock's Messiad, which, as we know, served as a magnificent epic of a new-age German myth, being crucial to the evolution of Germany as a political nation, the deities of the resurrected GermanScandinavian 'Olympus' inspiring new and heroic myths and deeds. (Vojvodic and Ioffe 2019). All this is to emphasize that the suggestive role of neomythological literature in 19th century Western Europe was truly immense, from Goethe's Prometheus and Ganymede to Schiller's Triumph of Victors and Ceres' Complaint.

Our special volume reinforces the study of ideas focused on "new religious ambiance" and "new myth", i.e., a modified mythological substance of the New Age (as opposed to classical antiquity and the Middle Ages), at least, in part. In a sense we are developing the mythocentric tradition initiated by F. Schelling and the Jena school of German mystical Romanticism, reflected in the critical (re)mythologizing of Wagner and the 'new philosophy' of Nietzsche, bastioned further by the new 'mythological criticism' - from J. Fraser to C.G. Jung (later followed by F. Raglan and R. Graves), and to the more recent Russian (originally Soviet) studies by Vladimir Toporov and his colleagues such as Zara Mints, Eleazar Meletinsky, Boris Uspensky and Sergei Nekliudov. ${ }^{5}$

The dominant point of this mythocriticism (whence neomythologism would evolve) was the dominant role of the myth-narrative in enriching the cultural and creative history of humanity. The influential monograph by Canadian literary scholar Northrop Frye (Anatomy of Criticism), published in the late fifties of the twentieth century, is also of crucial importance, here, inasmuch as he was one of those who brought the notion of a mythological substratum to modern academic scholarship on culture and literature. A modern Russian researcher of mythological discourse in folklore, Sergei Nekliudov, rightly 
observes that when speaking about textual realization of myth we should remember that it is 'multidimensional' and that "mythological messages are transmitted on different levels of tradition" (cf. Nekliudov 2000). Speaking of the semiotic component of mytho-research, Nekliudov explains how myth-encoding depends directly upon the variety of 'cultural texts' (referring to the Toporov's and Lotman's pioneering scholarship).

The narrative concept of 'magic' appears to parallel the concepts of 'myth' and 'religion', embracing both folk or peasant belief systems as well as Western European 'intellectual' mythology, artificial religion and magic, per se, in the complex esoteric tradition of both the Renaissance and the New and Modern eras. European culture has created an "intellectual" magical tradition which is rather mystical-occult, spiritualistic, hypnotic, remedial, artistic and even charlatan. It has also influenced Russian literature and writers, as well as the theurgy practiced by many Russians of the Symbolist period: a synthesis of music, poetry, color effects and ritual action capable, manifestly, of changing both time and the physical world, like a magical ritual (see a detailed collection of sources on theurgy in Lewy 2011; also, Petrov 2003). Separate avenues of enquiry are theosophy and anthroposophy, which also aim at a rational synthesis of the sciences so as to manage the explicit and hidden subjects of the universe (see on the topic of theosophy and various currents connected with it in Russia: Carlson 1993).

It is challenging enough to draw a clear historical and theoretical border between myth, magic and religion on the one hand, and esoteric science, philosophy, medicine, art on the other. An important topic is the literal and metaphorical attribution of magical functions to a person of the arts (in particular, literature), who could be perceived as a special kind of 'magician' (Kris and Kurz [1934] 1979), even if magic occupies a much larger place in literature (cf. the shocking 'bourgeois consciousness' narrative of Apuleius with his descriptions of transgressive (often erotic) magic in the Golden $A s s^{6}$ ) than it does in our daily life. There are many different forms or 'faces' of magic in the canonical literature of Western Europe. Consider, for example, one of the main protagonists of Shakespeare's play The Tempest, wherein the art of Prospero is to achieve existential world supremacy through incantatory magic. In the celebrated work of John Keats, 'Ode to a Nightingale'written in 1817 we read the virtually modernist lines: "Charm'd magic casements, opening on the foam" (Ioffe et al. 2017). In addition to the metaphorical and religio/mythological use of the word magic and its derivatives, we are talking about a special kind of 'magic air' that controls the movement of material objects, in this case, the ship itself. In Keats' poetical universe, magic is always associated with the imagination of the author, for he uses words as hidden spells-indeed, one of Keats's sources may have been Edmund Spencer's famous poem The Faerie Queene (1590). One may also recall the special sylph-sylphs described by Paracelsus, the magical spirits of the air, mentioned along with the gnomes as the infernal spirits of the earth, as well as Alexander Pope's odd nymphs and salamanders in his mock-heroic and magical-ironic work, The Rape of the Lock (1712) (cf.: McIntos 1998, p. 108).

This kind of quasi-romantic use of magic in 'high' literature is characteristic of the Renaissance and modern times. A celebrated German occult polymath Heinrich Cornelius Agrippa von Nettesheim (1486-1535) turned magic into the worldview of an active and vital individual, giving rise to a special (neo) platonic synthetic motif. Subsequently, in 1818 the "Agrippian" tradition leads into the debut of Mary Shelley and the narrative images of Victor Frankenstein. In this context, we also recall Christopher Marlowe and his celebrated text "The Tragical History of the Life and Death of Doctor Faustus" (1593), based on the popular book about Doctor Faust (see Zhirmunsky 1978). The same archetypal plot leads to Goethe and his mytho-tragedy Faust published in 1829. Similarly, Agrippa is in the semantic kernel of the novel The Fiery Angel, written by Russian "modernist/symbolist magician" Valery Bryusov. We might also mention William Butler Yeats with his intellectual nationalfolklore magical hypostasis of occultism. Ultimately, European "fantastic realism" is also important (with authors such as Jan Pototsky, Gerard de Nerval, Théophile Gautier, Villiers de L'Isle-Adam) as well as the latest South American magic realism (Miguel Angel Asturias 
and Gabriel García Márquez, and, with somewhat less relevance, also Julio Cortazar and Jorge Luis Borges) (Vojvodic and Ioffe 2019).

For Ernst Cassirer (Savodnik 2003) and Levi-Strauss (1999) the esoterica of myth crystallizes as a kind of separate creation, parallel to the signs of verbal language, the enzymatic substance of a metaphysical 'story of a special kind'. For Claude Lévi-Strauss, as his numerous works demonstrate, it was not so much the semantic as the ideographic isolation of specific pre-elements that, in fact, fund the spectral existence of the UR-myth, per se. Lévi-Strauss often proposed to designate such elementary protoreligious units as special myths, or 'elementals', which, to a greater or lesser degree, are responsible for the visibility of the mytho-narrative structure. In turn, this intricate composition of mythological fabric proves to be similar to the musical (melodic and melismatic) orchestrated system of signs. The narrative of myth can thus recreate the complex sonoric score of an anonymous form of hidden authorship. Intricate relations between myth and music remain quite intriguing ones. (Levi-Strauss 1999).

The semiotic domain of signs and signification mentioned above would seem to be crucial for understanding the conceptualization of neomythologism in Slavic literatures and cultures over the last hundred and fifty years or so. Alexey Losev furnished a successful definition of myth as an unfolded magic name, serving further as a basis for his idea that "myth is a word/name "[which] unfolded towards meaning and idea,-the name given as a contemplated, sculpted semantic picture of the essence and its destiny in the other-being". Losev continues this line of thought, linking primordial magic with the mytho-word as such: "Magic is the name moving in the direction of Sophia, the name given as the realized reality and life of otherness; euchology is the name moving in the direction of pure energy, the name meaningfully proceeding from essence to otherness, meaningfully and energetically, intelligently transforming the fragments of intelligence of this otherness and returning to essence together with an intelligently transformed otherness" (Losev 1992, p. 231). Losev also offers a rather typical example of a special magical myth-name, quoting an incantatory prayer in the rite of the expulsion of the demonic forces (from the Trebnik of Peter of the Grave): “ . . here I will have to finish the phenomenological-dialectical concept of myth. Myth as an expanded magical name can no longer be analyzed further ... Here is the final, indivisible, and central point of the meaning of myth per se." (Losev 1992).

Scholarship and science cannot, as the 19th-century positivists hoped, simply 'displace mythology' because "science does not solve such general metaphysical problems as the meaning of life, the purpose of history, the mystery of death, etc., while mythology still claims to solve them" (Meletinsky 2000, p. 5). Myth intends to resolve what is beyond the possibilities of science, it subsumes the metaphysical problems of human life, questions of birth and death, or again, the problematic questions of the existence of the absolute beginning and the absolute end. As Toporov notes, society is interested in unification "precisely because it consciously or unconsciously distinguishes in it certain guarantees of its security, an opportunity to overcome existential crisis, to manage and control members of this collective" (2010, p. 12). Some features of mythological thinking are preserved in mass consciousness, together with elements of philosophical and scientific knowledge (Tokarev and Meletinsky 1987, p. 15), but the endeavor to revive myth as a functioning system in its archaic form in modern society is impossible, if not utopian. It can, however, be an issue of influential 'remnants of the primordial mentality' (Eliade 2000, p. 171), which still form an important component of human existence.

Given the meaning of archaic myth and its understanding in contemporary society and culture, the concept of neomythologism could be linked with the culture of the twentieth and twenty-first centuries. A 'neomythological consciousness' appears to be one of the main directions of cultural vogue in the entire twentieth century-during the deliberations about the omnipotence of the (divine) Logos versus the crisis of natural scientific knowledge, eliciting interest in the irrational and the unconscious. It is in the development of all kinds of simulation practices and the crisis of logocentrism (for example, with Lyotard) that 
the culture of the 20th and the 21st centuries directs attention to the basic principles of mythological thinking. Contemporary technology supports this, at least, in part.

The rudimentary traces of neomythological and semi-religious thinking inherent in modern times are initially revealed in the complex poetics of the Russian modernists. Zara Mints in her pioneering article "On 'Neo-Mythological' Texts in the Oeuvre of Russian Symbolists" (2004) discusses the poetics of Blok, Merezhkovsky, Bely and Sologub, emphasizing that in the 'neomythological' texts of Russian symbolism the 'plan of expression' is determined by valves of 'contemporary or historical life' or the pictorial 'history of the lyrical self', while the 'content plan forms the correlation of the depicted with myth'. Accordingly, myth assumes the function of a language, or even of a cipher-code, revealing the implicit meaning of what is occurring within any given narrative (2004, p. 67). Mintz distinguishes folklore fiction during the period of Romanticism from the (neo)mythological world of the Symbolists, when the universe of the artistic text is endowed with 'ontological' existence and an 'ineffable truth', i.e., is equated with myth, affirming that the first mythic texts of the Symbolists were essentially narrative novels understood as 'myths about the world' and requiring a broad, discursive vision. Similarly, one of the pioneers of the post-war academic study of myth, Eliade, observes that the novel as a kind of institution in modern society has earned the place of a special mythological narrative (2000, p. 179) reminiscent of the ideas which Meletinsky expressed in his influential collection From Myth to Literature (Meletinsky 2000, p. 130). Meletinsky considers Mann, Joyce, and Kafka to be the initiators of such a 'mythological' novel, because they use mythopoetical models and critical narrative elements; in fact, mythology becomes their 'instrument of narrative structuring' (Ibid.)

Our special volume opens with a detailed scholarly essay by academician Andrey Toporkov (Russian Academy of Sciences, Alexey M. Gorky Institute of World Literature) "The Carol About the Pagan Rite of Sacrifice of a Goat and Its Interpretation in Russian Scholarship of the 19th-20th Centuries". The essay discusses the publications of Russian folklore along with authentic texts and several literary stylizations based on folklore. The article traces the history of one such pseudo-folkloric text-a carol that was first published by Ivan Petrovich Sakharov in 1837 and which attracted particular interest on the part of researchers of Slavic mythology, because it described an old man sacrificing a goat. In this pseudo-folkloric text, several generations of historians saw a description of a ritual which pagan Slavs performed in ancient times. Considering the carol as a historical document, researchers of mythology elaborated their interpretations based on the supposed time of its appearance, the nature of its genre, plot and the individual details. In this way, Sakharov's pseudo-folkloric creation found an eager audience among scholars, stimulating their imagination in picturing the life of pagan Rus'.

Toporkov's paper is followed by academician Svetlana M. Tolstaia (Russian Academy of Sciences, Institute for Slavic Studies, InSlav): “Eastern Christianity and Popular Culture: Mechanisms of Interaction". According to Tolstaia, in traditional Slavic folk culture, Christianity is a foreign, borrowed cultural model, while the oral tradition is native and familiar. The different areas of folk culture were influenced in varying degrees by the Christian tradition. The most forward area of Slavic folk culture dependent upon Christianity was the calendar, the cardinal elements of Christian content of which, in many cases, it accepted, albeit superficially, reinterpreting them in concordance with traditional mythological conceptions and notions. The same can be observed about the folk cult of saints. The Christian saints replaced pagan gods which over time entered the system of folk ideas, beliefs and rituals. The mechanism for regulating the balance between man and the world is a system of prohibitions, the violation of which is recognized as sin and is punished by natural disasters, death, disease and human misfortunes. The Slavic folk tradition adapted not only the individual elements, structures and semantic categories of Christianity, but also the texts, plots, motifs, and themes elaborated in various genres of folklore. Therefore, the pre-Christian folk tradition of the Slavs assimilated many Christian concepts, symbols, and texts, translated them into its language and filled them with its own content. 
What follows in our collection is a scholarly paper by Dieter Stern (Ghent University) "Ruthenian Sacred Geography of the Baroque Age-the Role of Devotional Songs in Shaping Landscapes of Popular Worship in the Polish-Lithuanian Commonwealth". The article explores how the newly founded and highly contested Christian confession of the Greek Catholics or Uniates employed strategies of mass mobilization so as to establish and maintain their position within a contested confessional terrain. The Greek Catholic clerics, above all, monks of the Basilian order, fostered an active policy of acquiring, founding and promoting Marian places of grace in order to create a sense of belonging among their flock. The author argues that folk ideological notions concerning the spatial and physical conditions for the working of miracles were seized upon by the Greek Catholic faithful to establish a mental map of the grace of their own. Especially, the Basilian order took care to organize collective events such as annual pilgrimages and crowning celebrations for miraculous images and promote Marian devotion via reports of miracles and songs about icons in an attempt to define what it means to be a Greek Catholic in terms of sacred territoriality. The paper is followed by Aleksey Yudin (also from Ghent University) with his essay "Christian Saints in Russian Incantations: Names, Images and Functions". This paper discusses the Christian saints most often mentioned in Russian incantations: such as George, Nicholas, Florus and Laurus, Kossma and Damian, Zosima and Savvaty of Solovki, as well as the semi-apocryphal saints Sisinius and Solomonia, the first six being among the most popular saints in Russian folk Orthodoxy. The article describes the names and attributes of the saints and their functions in Russian folk magic. Depending on their magical function, the protagonists of the incantations can act as helpers, protectors and healers, assisting in various practical areas of life and protecting against real and magical dangers and helping to heal diseases and wounds.

A related topic is explored by Aleksandra Ippolitova (Russian Academy of Sciences, Alexey M. Gorky Institute of World Literature) in "Sacred and Profane: Religious Taboo in Russian Incantations and Herbals". This paper explores linguistic taboos (euphemisms, omissions, and others)—an essential part of Slavic verbal and written culture-, analyzing cryptography as a taboo mechanism in the magical texts of the manuscript tradition of the 17th and 18th centuries such as handwritten incantations and herbals. In the latter, for example, cryptography taboos "sinful" or artful topics (love magic, magic used against courts and authorities, sorcery, jinx, and 'secret' knowledge), and in the texts which were wont to bear a sacral meaning (incantations and prayers).

With the detailed research paper by Nicoletta Misler (Istituto Orientale, Napoli, Italy) and John E Bowlt (University of Southern California, Los Angeles, CA, USA) "Painting is Believing: Pavel Filonov and His Icon of St. Catherine" we open a different corpus of essays. The authors discuss the Orthodox icon which Pavel Filonov (1883-1941) painted in 1908 or 1909 for his sister, Ekaterina, placing it within the broader context of his oeuvre, his family and his understanding of 'religiosity'. Referring to Filonov's system of Analytical Art and to what he called 'madness', the authors focus on the particular technical devices which he used in the icon and on the podlinnik (or primer) from which he copied the main elements. Reference is also made to other religious motifs in Filonov's art such as the Magi, Flight into Egypt and Crucifixion.

Dorota Walczak-Delanois (Université Libre de Bruxelles) presents a detailed account of the "Poems by Polish Poetesses and the Burning Issue of Religion" which helps uncover the presence of religion and the particular evolution of lyrical matrixes connected to religion in the Polish poems of female poets, a notable presence of women lying at the roots of the Polish literary and lyrical traditions - for centuries, the image of a woman with a pen in her hand was one of the most important imponderabilia, although, until the 19th century, Polish female poets continued to be rare. In any case, whenever women poets appear, they are linked to institutions such as convents, where female intellectuals were able to enjoy relative liberty and refuge, even if many of the poetic forms they used in the 16th, late 17th and 18th centuries were typically male in origin and followed established models. In the 19th century, the specific image of the mother as a link to the religious portrait 
of the Madonna and the Mother of God (the first Polish poem presents Bogurodzica, the Virgin Mary, the Mother of Jesus) reinforces the new female presence. Indeed, after Adam Mickiewicz's poem Do matki Polki ('To Polish Mother'), the term "Polish mother" becomes a separate literary, epistemological and sociological category. Throughout the 20th century (with some exceptions), the impact of Romanticism and its poetical and religious models remained alive, even if they underwent modifications. The period of communism, as during the Period of Partitions and the Second World War, privileged established models of lyric, where the image of women reproduced Romantic schema from 19th-century poetical canons, closely linked to religion.

The same territory is explored in a seminal paper by Petra James (Université Libre de Bruxelles), "Myth, Ethics and Sacrifice in Jan Patočka's Aesthetic Thinking". Intense and systematic scholarly interest in the relation of Patočka's phenomenology to religion and Christianity is recent, attracting particular attention over the last decade. Thus far, the topic has mainly been studied from philosophical and theological perspectives and the extensive body of Patočka's cultural writings has failed to attract the intellectual community at large. This article focuses on the analysis of cultural archetypes in Patočka's cultural writings related to the topic of religion and Christianity: the archetypes of the Faustian figures of Patočka's creative writings, whether Goethe's Faust, Goethe's Marguerite, or Mann's Adrian Leverkühn, are all Socratic-Christic avatars that personify Patočka's philosophical concept of "care for the soul" in the modern age. The legacy of Plato's Greek philosophy and that of Western Christianity, as presented by Patočka, insists on the universally shared existential experience of finitude that should be grasped as a positive challenge in the quest for meaning. Patočka's "titanism" and the archetypal titanic figures of his writings are manifestations of this universal effort, indicating that a culturological approach to Patočka's thinking on religion and Christianity might prove to be especially relevant.

Raymond Detrez (Ghent University) presents a paper "Tensions Among Religious Communities in Interwar Bulgaria. Observations by Flemish Missionaries in the Diocese of Nicopolis". Premodern Ottoman society consisted of four major religious communities, Muslims, Orthodox Christians, Armenian Christians and Jews; the Muslim and Christian communities also included various ethnic groups, as did the Muslims, Arabs and Turks, Orthodox Christian Bulgarians, Greeks and Serbs who identified, in the first place, with their religious communities and considered ethnic identity of secondary importance. Living together for centuries, albeit segregated within the borders of the Ottoman Empire, Bulgarians and Turks (to a considerable extent) shared the same worldview and moral value system and tended to react uniformly to various events. For example, the Bulgarian attitudes toward natural disasters, on which this contribution focuses, seem not to have differed essentially from those of their Turkish neighbors, as both proceed from the basic idea of God's providence being intrinsic to these disasters. Despite the (overwhelmingly Western) perception of Muslims as passive and fatalistic, the problem of whether or not one had the right to escape the wrath of God was also deliberated in similar terms. However, in addition to a comparable religious mental make-up, social circumstances and administrative measures, the conditions of both religious communities, rather than cross-cultural influences, seem to provide a more plausible explanation for these parallels.

With the paper by Alexander Zholkovsky (University of Southern California, Los Angeles), we turn to Russian classics. His paper "To Be or Not to be God: Debating the Authorial Power in Dostoevsky" is focused on the issue of God in the oeuvre of the legendary Russian author, discussing the now widely accepted concept of Dostoevsky's dialogism - which alleges the author's equal empowerment of all his characters. Using examples from Crime and Punishment and The Brothers Karamazov, Zholkovsky focuses on instances of scene-staging based on the 'scripts' devised and enacted by some characters, and 'read', with varying success, by their targets. He documents the resulting 'discursive combat' among the characters, paying special attention to those 'playing at god' and, thus, the more 'authorial' among them. In several cases, the would-be 'divine' manipulation is shown to be consistently subverted by the Dostoevskian narrative. However, in one 
instance, where Aliosha Karamazov charitably scripts Captain Snegirev's behavior (the ensuing discussion of this episode) in Aliosha's conversations with Lise Khokhlakova, upholds Aliosha's right to play God with the Other- "for the Other's good", of course (not unlike the Grand Inquisitor).

Another academic from California, Igor Pilshchikov (University of California, Los Angeles) offers a fundamental paper "Gogol's The Nose Between Linguistic Indecency and Religious Blasphemy". Focused on Nikolai Gogol's absurdist narrative tale, "The Nose" (1835), the article is an investigation into the concealed representation of suppressed and marginalized libertine and antireligious discourses in nineteenth-century Russian literature. The author identifies overlooked idiomatic phraseology, forgotten specificities of the Imperial hierarchy (the Table of Ranks) and allusions to religious customs and Christian rituals that would have been apparent to Gogol's readers, while demonstrating how some were camouflaged to escape censorship in successive drafts of the work. Pilshchikov's research builds on the approaches to Gogol's language, imagery and plot developed by the Russian Formalists, Tartu-Moscow semioticians, and other scholars, who revealed the latent obscenity of Gogol's "rhinology" and the sacrilegious meaning of the very specific chronotope within the tale. An integrated analysis of these aspects helps us understand what the details of the story reveal about Gogol's religious and psychological crisis of the mid-1830s, revealing, for example, how he aggregated indecent Shandyism, social satire, and religious blasphemy into a single quasi-oneiric narrative.

Monika Spivak (Russian Academy of Sciences, Alexey M. Gorky Institute of World Literature; Andrey Belyi Museum, State Alexander Pushkin Museum) offers a paper titled "The 'Christology' of Belyi the anthroposophist: Andrei Bely and the Apostle Paul". This text focuses on Rudolf Steiner's perception of the Gospels and its impact on Bely's works. The latter had long valued Steiner's lectures on Christ and the Fifth Gospel, the "Anthroposophic" (relating to the philosophy of human genesis, existence, and outcome) Gospel, the knowledge of which had been received in a visionary way. In addition, Bely was an esoteric follower of Steiner who often quoted from Apostle Paul's 2 Corinthians, "Ye are our epistle written in our hearts, known and read of all men". The citation occurs in Bely's philosophical works (The History of the Formation of the Self-Conscious Soul, "Crisis of Consciousness"), autobiographical prose (Reminiscences of Steiner), the essay "Why I Became a Symbolist ... ", and letters to Ivanov-Razumnik and Fedor Gladkov. Bely's own anthroposophic and esoteric ideas relating to the gospel dicta are also examined. Resorting to a single quotation, Spivak shows the specifics of Bely's stance vis-à-vis the anthroposophist's perception of Christian texts. This furnishes a methodological meaning which helps us understand other Biblical quotations and images in the works of Bely, anthroposophical Christology also being the key to their deciphering

A scholar from St. Petersburg, Andrey A. Astvatsaturov (State University of St Petersburg SPBGU) presents "Franny's Jesus Prayer: Salinger and Russian Orthodox Spirituality". The text discusses The Way of a Pilgrim and The Pilgrim Continues His Way-a Russian Hesychast text that was first published in 1881 and translated into English in 1931. It has gained popularity in the English-speaking world thanks to J.D. Salinger, who mentions and re-narrates it in his stories 'Franny' and 'Zooey', and the reference has often been noted in both critical works on Salinger and studies dedicated to the book The Way of a Pilgrim. However, this is the first time that a scholar has attempted to provide a fundamental analysis of the textual interconnections between Salinger's stories and the radical Hesychast religious mind. In the article, the text of The Way of a Pilgrim is read within the framework of Salinger's stories and is interpreted as being significant to his later texts. From the Hesychast book, Salinger borrows several images and presents its philosophy as a spiritual ideal. At the same time, he approaches it with a certain irony, exposing several pitfalls and misconceptions in interpretations of the Jesus prayer, as illustrated by Franny, one of Salinger's characters. After illuminating Franny's mistakes and her peccant intention, Salinger reestablishes the Hesychast ideal and connects it with Søren Kierkegaard's principle of theistic existentialism 
Vadim Polonsky (Russian Academy of Sciences, Alexey M. Gorky Institute of World Literature) offers "Merezhkovsky's NeoChristianity of the Third Testament: From the Symbolist Historiosophy to the Right-Wing Politics", an article which places Dmitry Merezhkovsky's Chiliastic concept of the Three Testaments within a unified structure. The author analyzes the writer's integral system of Christological, anthropological, historiosophic idiomyths and meta-symbols, investigating the religious, philosophical and aesthetic geneses of the semantic transformation of traditional theological constructions and the doctrinal compilation of the dominant elements within Russian fin de siècle culture. We discover how modernist mythmaking alters political reality in Merezhkovsky's mind and draws him towards radical ideologies of the extreme left and right.

Henrietta Mondry (University of Canterbury, New Zealand) presents a paper on the related period "Synthesizing Religions: Vasily Rozanov's Phallic Christianity", Rozanov being one of the first Russian writers of the fin de siècle to create a nexus between the study of the history of world religions and the history of sexuality. Rozanov viewed Christian asceticism as a source of the disintegration of the contemporary family and Mondry examines his strategy to synthesize religions and to use pre-Christian religions of the Middle East as proof of common physical and metaphysical essence in celestial, human, animal and mythological human/animal/divine bodies. Mondry argues that while his rehabilitation of physical life by endowing it with religious value was socially positive, his self-proclaimed 'mission of sexuality', when politically motivated, was manipulative and incorporated the notion of the atavistic 'survivals'. In conclusion, the author explains that Rozanov's monistic search for the divine in the physical body, as well as his strategy for religious synthesis, were additionally driven by his doubts in the preeminence of Christian eschatology.

Irina Sakhno (Higher School of Economics, Moscow) presents another paper focused on the art of the avant-garde, "Apophatic Theology and Sacred Signs in the Russian Avant-Garde". The author discusses Kazimir Malevich's suprematist art in the context of negative (apophatic) theology and as a crucial tool in analyzing both the artist's theoretical conclusions and his new visual optics. Analysis indicates that the artist moved intuitively towards recognizing the ineffability of the multidimensional universe and perceiving God as the spiritual absolute. In his attempt to see the invisible in the formula of emptiness and nothingness, Malevich turned to the primary forms of geometric abstraction-the square, circle and cross-which he endowed with symbolic concepts and meanings, for the artist treated of his Suprematism as a method of perceiving the ineffability of the absolute. With the Black Square seen as a face of God, the patterns of negative theology rise to become a philosophical formula of primary importance. Malevich's series called Mystical Suprematism (1920-1922) confirms the presence of complex metaphysical reflection and apophatic thought, for not only does the series contain icon paraphrases and the Christian symbolism of the cross and mandorla, but it also advances the formula of the apophatic faith of the modern times, Suprematism presenting primary forms as universals of "the image of the future" and the energy of non-objective art.

Svetlana Efimova (Ludwig-Maximilians-Universität München) debates the question of God in Boris Parsternak in her paper entitled "The October Revolution as the Passion of Christ: Revisiting Doctor Zhivago and Its Contexts". The article offers a new interpretation of Doctor Zhivago in the cultural and historical context of the first half of the 20th century, emphasizing the interrelationship between religion and philosophy of history. Doctor Zhivago is analyzed as a condensed representation of a religious conception of Russian history between 1901 and 1953 and as a cyclical repetition of the Easter narrative. The bipartite narrative consists of the Passion and Resurrection of Christ as symbols of violence and renewal (liberation), while the novel as a whole cycles through this narrative several times, symbolically connecting the 'Easter' revolution (March 1917) and the Thaw (the spring of 1953). The sources of Pasternak's Easter narrative include the Gospels, Leo Tolstoy's philosophy of history, and pre-Christian mythology. The model of cyclical time in the novel brings together the sacred, natural and historical cycles. This concept of a cyclical 
renewal of life differs from the linear temporality of the apocalypse as an expectation of the end of history.

Our volume concludes with yet another paper on the relation between the Avantgarde and religious philosophy, Evgeny Pavlov (University of Canterbury, New Zealand) presenting a paper entitled "God is Everywhere, Possibly: Aleksandr Vvedensky's Tropes of Theology". Bringing vast textological evidence, this article focuses on the complicated questions of God, time and the new poetics of transcendence which find their intellectual roots in Russian Kantianism and epistemology of temporality.

Funding: This research received no external funding.

Conflicts of Interest: The author declares no conflict of interest.

\section{Notes}

1 See, for example, Lotman et al. (1987); Kozlov (2001); Tolstoi (1995); Toporkov (1997); Toporov (1967); Toporov (1988); Uspenskii (2018); Vernant and Vidal-Naquet (1996)

2 On the complex-dialectical development of this whole complex of Barthian myth-ideas, see in particular Ioffe (2008a, 2008c).

3 Of the relatively recent interdisciplinary studies of the theory of myth and the mythical in culture, we note the following: Doty (2004); Adamenko (2007); Ellwood (2008); Bennett and McDougall (2013); Marderness (2009); Coupe (1997).

4 For a further look at myth in an anthropological vein, see also Malinowski (2004) and Durkheim (2018) as well as Moss (1996). See many theoretical and applied variations on the definition of myth and the mythic in: Barthes (2004); Weiman (1975); Grigoriev (1987); Diakonov (1990); Dumezil (1986); Durkheim (2018); Ivanov (2005); Ioffe (2006a, 2007, 2009); Caillois (2003)); Kanevskaia (2000); Lifshitz (1980); Levi-Strauss (1985, 1999); Lord (1994); Losev (1982, 1992, 1994); Lotman and Mintz (1981); Lotman and Ouspensky (1973); Meletinsky (1995); Nekliudov (2000); Turner (1983); Tolstoy (1995); Toporov (1995); Hübner (1996); Buonanno (2018); Cassirer (1946); Cassirer (1955); Coupe (1997); Csapo (2005); Cunningham (1973); Thomas (1978); Day (1984); Ioffe (2006b); Kirk (1970); Liszka (1989); Segal (1998); Strenski (1987); Vickery (1966). See, in particular, Mintz (2004); Toporov (2010); Meletinsky (1995); Nekliudov (2000). See also Vojvodic and Ioffe (2019).

5 See also the relevant provisions in the work of Lotman and Ouspensky (1973), which, in a certain sense, contrasts with and complements the mytho-philosophical views and the entire ideological position of Losev. See context and details in Losev (1992, pp. 231-32).

6 The preferecne of the word-choice for Ass instead of say Donkey appears to be shocking enough on its own.

$7 \quad$ See many corresponding later texts in our collection focused on modernism and the avant-garde: Ioffe and White (2012). See also Ioffe $(2006 a, 2017)$.

\section{References}

Adamenko, Victoria. 2007. Neo-Mythologism in Music: From Scriabin and Schoenberg to Schnittke and Crumb. Hillsdale: Pendragon Press. Barthes, Roland. 2004. Mif segodnia. In Mifologii. Moskva: Izdatel'stvo Sabashnikovykh, pp. 265-323.

Bennett, Pete, and Julian McDougall, eds. 2013. Barthes' Mythologies Today: Readings of Contemporary Culture. London: Routledge.

Buonanno, Michael. 2018. The Meaning of Myth in World Cultures. Jefferson: McFarland.

Buck, C. D. 1949. A Dictionary of Selected Synonyms in the Principal Indo-European Languages. A Contribution to the History of Ideas. Chicago and London: University of Chicago Press.

Caillois, Roger. 2003. Myth, Chelovek i sakralnoe. Moscow: OGI.

Carlson, Maria. 1993. No Religion Higher Than Truth: A History of the Theosophical Movement in Russia, 1875-1922. Princeton: Princeton UP.

Cassirer, Ernst. 1946. Language and Myth. Translated by Susanne K. Langer. New York: Dover Publications.

Cassirer, Ernst. 1955. The Philosophy of Symbolic Forms vol. 2 Mythical Thought. New Haven: Yale UP.

Coupe, Laurence. 1997. Myth. London: Routledge.

Csapo, Eric. 2005. Theories of Mythology. Hoboken: Wiley-Blackwell.

Cunningham, Adrian, ed. 1973. The Theory of Myth. Six Studies. London: Sheed \& Ward.

Day, Martin S. 1984. The Many Meanings of Myth. Lanham: University Press of America.

Diakonov, M. Igor. 1990. Archaicheskie Mythy Vostoka i Zapada. Moscow: Nauka.

Doty, William G. 2004. Myth: A Handbook. Westport: Greenwood Press.

Dumezil, Georges. 1986. The Supreme Gods of the Indo-Europeans. Moscow: Nauka.

Durkheim, Émile. 2018. Elementarnye Formy Religioznoi Zhizni. Moskva: Delo.

Eliade, Mircea. 2000. Aspekty Mifa. Moskva: Akademicheskii proekt.

Ellwood, Robert S. 2008. Myth: Key Concepts in Religion. London and New York: A\&C Black.

Frisk, H. 1960. Griechisches etymologisches Wörterbuch, Band I. Heidelberg: Carl Winter.

Grigoriev, Nikolai V. 1987. Sootnosheniia mifa i iskusstva v kul'ture. In Iskusstvo v sisteme kul'tury. Leningrad: Nauka. 
Grygar, Mojmír. 2007. Znakotvorchestvo. Semiotics of the Russian Avant-garde. St. Petersburg: Akademicheskii proekt.

Hübner, Kurt. 1996. Istina Mytha. Moscow: Respublika.

Ioffe, Dennis, and Frederick White, eds. 2012. The Russian Avant-Garde and Radical Modernism. Boston: Academic Studies Press.

Ioffe, Dennis, Andrey Toporkov, and Aleksey Yudin. 2017. Magic, Folklore, Literature: An Introduction. Russian Literature 93-94: 2-45.

Ioffe, Dennis. 2006a. Modernism in the Context of Russian Life-Creation: Lebenskunst and the Theory of Life $\Leftrightarrow$ Text Sign Systems. New Zealand Slavonic Journal 40: 22-55.

Ioffe, Dennis. 2007. Russian Religious Criticism and the Problem of Imiaslavie (o. Pavel Florenskii, o. Sergii Bulgakov, A.F. Losev). Kritika i Semiotika 11: 109-73.

Ioffe, Dennis. 2008a. The Problem of Author as Scriptor and the Postmodern Theory of Literature. Mirgorod: Journal, Posviashchennyi Voprosam Epistemologii Literaturovedenii (Journal of the Epistemology of Literary Research) 1.1: 93-108.

Ioffe, Dennis. 2008b. Velimir Khlebnikov, Islamic Mysticism, and Oriental Discourse. In Doski Sudby Velimira Khlebnikova: Tekst $i$ Konteksty. Moscow: Tri Kvadrata, pp. 547-637.

Ioffe, Dennis. 2008c. Gustave Chpet, la religion et le probleme du signe. In Gustave Chpet et Son Heritage Aux Sources Russes Du Structuralisme Et De La Semiotique, Slavica Occitania. Toulouse: Université Toulouse-Jean Jaurès, vol. 26.

Ioffe, Dennis. 2009. Sign Theory and the Role of Ancient Egypt in the Context of Khlebnikov. In Russian Anthropological School. Russian State University for Humanities. Moscow: RGGU, vol. 6, pp. 241-59.

Ioffe, Dennis. 2017. The Politics of Modernism in Russia: A Reassessment. Russian Literature 92: 3-17.

Ioffe, Jeremiah. 2006b. Symbolism' (mystical idealism); Constructivism; Expressionism and Surrealism. In Selected: 1920s-30s. From Culture and Style, Synthetic Art Theory, Synthetic Art Studies and Sound Cinema. Compiled and Edited by. M. S. Kagan. St. Petersburg: Petropolis, pp. 197-251.

Ivanov, Viach. 2005. Egypt of the Amarna Period in Kharms and Khlebnikov. In Paper presented at the Centenary of Daniil Kharms: Proceedings of the International Scientific Conference, St. Petersburg, Russia, August 24-26; pp. 80-90.

Kanevskaia, Marina. 2000. History and Myth in the Postmodern Russian Novel. From the Proceedings of the Russian Academy of Sciences. Series of Literature and Language 59: 37-47.

Kirk, Geoffrey S. 1970. Myth: Its Meaning and Functions in Ancient and Other Cultures. Cambridge: Cambridge UP.

Kozlov, Alexander S. 2001. Myth and Mythological Criticism. In Literary Encyclopedia of Terms and Concepts. Edited by Alexander N. Nikolyukin. Moscow: Intelvalk, pp. 559-62.

Kris, Ernst, and Otto Kurz. 1979. Legend, Myth, and Magic in the Image of the Artist. New Haven: Yale University Press. First published 1934.

Levi-Strauss, Claude. 1985. How Myths Die. In Foreign Studies in the Semiotics of Folklore. Moscow: Universitetskaia kniga.

Levi-Strauss, Claude. 1999. Mythologiques. 4 vols. Moscow: Universitetskaia kniga.

Lewy, H. 2011. Chaldaean Oracles and Theurgy: Mysticism, Magic and Platonism in the Later Roman Empire, 3rd ed. par Michel Tardieu, avec un supplément 'Les oracles chaldaïques'. Paris: Institut des Etudes Augustiniennes.

Lifshitz, Mikhail A. 1980. Mythology Ancient and Modern. Moscow: Iskusstvo.

Liszka, James Jakob. 1989. The Semiotic of Myth: A Critical Study of the Symbol. Bloomington: Indiana University Press.

Lord, Albert B. 1994. The Singer of Tales. Moscow: Nauka.

Losev, Aleksei F. 1982. Sign—Symbol—Myth. Moscow: MGU.

Losev, Aleksei F. 1992. Myth is an Expanded Magical Name. Symbol 28: 231-32.

Losev, Aleksei F. 1994. Myth. Number. Essence. Moscow: Mysl'.

Lotman, Yury M., and Boris A. Ouspensky. 1973. Myth-Name-Culture. Trudy Po Znakovym Sistemam VI: 282-303.

Lotman, Yury M., and Zara G. Mintz. 1981. Literature and Mythology. Proceedings: Sign Systems 13: 35-55.

Lotman, Yury M., Zara G. Mintz, and Eleazar M. Meletinsky. 1987. Literature and Myths. In Encyclopedia: Mythy Narodov Mira. Moscow: Sovetskaia Encyclopedia.

Malinowski, Bronisław. 2004. The Argonauts of the Western Pacific. London: Routledge and Sons.

Marderness, William. 2009. How to Read a Myth. New York: Humanity Books.

McIntos, Charles. 1998. The Rosicrucians: The History, Mythology, and Rituals of an Esoteric Order. Boston: Weiser Books.

Meletinsky, Eleazar M. 1995. Poetics of Myth. Moscow: Nauka.

Meletinsky, Eleazar M. 2000. From Myth to Literature. Textbook on the Theory of Myth and Historical Poetics of Narrative Genres. Moscow: Vostochnaia literatura.

Mintz, Zara. 2004. On Some Neomythological Texts in the Work of Russian Symbolists. In Blok and Russian Symbolism: Selected Works in Three Volumes. St. Petersburg: Iskusstvo, Available online: http:/ /www.ruthenia.ru/mints/papers/neomifologich.html (accessed on 14 May 2017).

Moss, Marcel. 1996. Society. Exchange. Personality. Works on Social Anthropology. Moscow: Nauka.

Nekliudov, Sergei Yu. 2000. The Structure and Function of Myth. Myths and Mythology in Modern Russia. Edited by Karl Eimermacher, Folk Bomsdorff and Gennadii Bordugov. Moscow: AIRO-XX, pp. 17-38.

Otto, Rudolph. 2008. Sviaschennoe. Das Heilige: Uber das Irrationale in der Idee des Gottlichen und sein Verhaltnis zum Rationalen. Sankt Petersburg: SPBGU University Press.

Petrov, A.V. 2003. Fenomen theurgii. Filosofia i magia v antichnosti. Sankt Peterburg: RHGI.

Savodnik, Peter. 2003. Ernst Cassirer's Theory of Myth. A Critical Review. A Journal of Politics and Society 15: 447-59. 
Segal, Robert A. 1998. The Myth and Ritual Theory. Hoboken: Wiley-Blackwell.

Strenski, Ivan. 1987. Four Theories of Myth in Twentieth-Century History: Cassirer, Eliade, Levi Strauss and Malinowski. Iowa City: University of Iowa Press.

Tambiah, Stanley J. 1990. Magic, Science, Religion, and the Scope of Rationality. Cambridge: University Press.

Thomas, Keith. 1978. Religion and the Decline of Magic: Studies in Popular Beliefs in Sixteenth and Seventeenth-Century England. London: Weidenfeld \& Nicolson.

Thorndike, Lynn. 1958. A History of Magic and Experimental Science. 8 vols. New York: Macmillan.

Tokarev, Sergei A., and E. M. Meletinsky. 1987. Mythology. In Myths of the Peoples of the World. Moscow: Sovetskaia Encyclopedia, pp. 11-22.

Tolstoi, N. I. 1995. Iazyk i narodnaia kul'tura. Ocherki po slavianskoi mifologii i etnolingvistike. Moskva: Indrik.

Tolstoy, Nikita I. 1995. Language and Popular Culture. Essays on Slavic Mythology and Ethnolinguistics. Moscow: Indrik.

Toporkov, Andrey. 1997. Teoriia Mifa V Russkoi Filologicheskoi Nauke XIX veka. Moscow: Indrik.

Toporov, Vladimir N. 1967. Towards the Reconstruction of the Myth of the World Egg (on the Material of Russian Fairy Tales). In Trydy Po Znakovym Systemam. Tartu: University Press, vol. III.

Toporov, Vladimir N. 1987. Cosmogonic Myths. In Myths of the Peoples of the World. Moscow: Sovetskaia Encyclopedia.

Toporov, Vladimir N. 1988. On Ritual. Introduction to the Problematics. In Archaic Ritual in Folklore. Moscow: Nauko.

Toporov, Vladimir N. 1995. Myth. Ritual. Symbol. Image: A Study in the Field of Mytho-Poetic. Moscow: Progress.

Toporov, Vladimir N. 2010. World Tree. Universal Sign Systems. Moscow: RPDR, vols. 1 and 2.

Turner, William. 1983. Symbol and Ritual. Moscow: Nauka.

Uspenskii, Boris A. 2018. Issledovaniia po russkoi literature, fol'kloru i mifologii. Moskva: Common Place.

Vernant, Jean-Pierre, and Pierre Vidal-Naquet. 1996. Myth and Tragedy in Ancient Greece. New York: Zone Book.

Vernant, Jean-Pierre. 1996. Myth and Society in Ancient Greece. Translated by Janet Lloyd. New York: Zone Book.

Versnel, Henk. 1991. Some Reflections on the Relationship Magic-Religion. Numen 38: 177-97. [CrossRef]

Vickery, John B., ed. 1966. Myth and Literature: Contemporary Theory and Practice. Lincoln: University of Nebraska Press.

Vojvodic, Jasmina, and Dennis Ioffe. 2019. K voprosu o neomifologizme v literature. Russian Literature 107-108: 2-31.

Wax, Murray, and Rosalie Wax. 1963. The Notion of Magic. Current Anthropology 4: 495-512. [CrossRef]

Weiman, Robert. 1975. Myth and Ritual. In Literary History and Mythology. Essays on the Methodology and History of Literature. Moscow: Progress Publishers, pp. 279-85.

Zhirmunsky, Victor M. 1978. Legenda o doktore Fauste. Edited by Victor M. Zhirmunsky. Moscow and Leningrad: Nauka. 